\title{
Focus on appendices in Dutch ${ }^{*}$
}

\author{
Ton van der Wouden \\ Universiteit Leiden/HIL
}

\section{Introduction}

Dutch sentences may be augmented with additional material after a comma break (to a certain extent, the same holds for English). In (1), a few examples (after Haeseryn et al. (1997:1397)) are given. ${ }^{1}$

(1) a. Morgen zou hij haar ${ }_{i}$ weer zien, zijn geliefde $e_{i}$. tomorrow would he her again see his beloved 'Tomorrow would he see her again, his beloved'

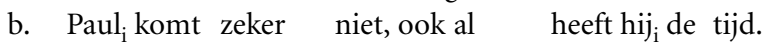
Paul comes certainly not also already has he the time 'Paul will certainly not come, even if he has the time'

In the remainder, we will refer to the part before the comma as main sentence, whereas the final part will be called appendix. ${ }^{2}$

Particles, especially focus particles, are found quite often in appendices: ${ }^{3}$

(2) a. We gaan nog niet naar huis, nog lange niet nog lange niet. ${ }^{4}$ we go yet not to home yet long not yet long not 'We're not going home yet, no, we aren't'

b. De trein vertrok, net toen we op het perron kwamen. the train left just when we on the platform came 'The train left right at the moment we arrived at the platform'

In the first part of this paper we will be concerned with general syntactic, semantic, pragmatic and phonological properties of appendices. In the second part, we will deal with the particles found in appendices, which will be shown to often be focus particles. In the third and final part, the former two parts will be connected. 


\section{General properties of appendices}

Following the description in Haeseryn et al. (1997: 1387-1400), we may distinguish constituent-like appendices and sentence-like ones. In the first type, the appendix looks like a constituent (but cf. below) that either clarifies or modifies a constituent in the main sentence (3a), or adds such a constituent (3b). In the second type $(4 a-b)$, the appendix consists of some kind of subordinate clause. ${ }^{5}$

(3) Constituent-like appendices

a. Ik kan hem $\mathrm{i}_{\mathrm{i}}$ niet uitstaan, die jongen $\mathrm{i}_{\mathrm{i}}$

I can him not stand that boy

'I can't stand that boy'

b. Otje ging naast haar vader zitten, hijgend en zwetend.

Otje went next her father sit panting and sweating

'Panting and sweating, Otje sat down next to her father'

(4) Sentence-like appendices

a. Italië is een fijn land, (vooral) als je van zon houdt. Italy is a nice country especially if you of sun hold 'Italy is a nice country, (especially) if you like the sun'

b. Winnen kun je niet, hoe hard je ook je best doet. win can you not how hard you Part your best do 'You really cannot win, whatever your efforts'

\subsection{On the syntax of appendices}

Contrary to what the discussion of appendices in Haeseryn et al. suggests by not mentioning many of the possibilities, almost any constituent may be varied upon in the appendix: subjects, objects, prepositional phrases, adverbial material, etc. ${ }^{6}$ Note, moreover, examples such as the ones in (5), in which the appendix material does not correspond to a single constituent, at least not in the traditional sense: in (5a) the appendix consists of a focus particle, a 'subject' and a 'direct object', in (5b) we find a focus particle, a negation particle and a prepositional phrase, and in $(5 \mathrm{c}) \mathrm{a}$ modal auxiliary and a pronominal 'subject'.

(5) a. Iedereen heeft iedereen gekust, zelfs Jan Vincent. everybody has everybody kissed even Jan Vincent 'Everybody kissed everybody, even Jan and Vincent kissed'

b. Zeg niets, vooral (niet) tegen Marie. say nothing especially not against Marie 'Don't say anything to anybody, let alone to Mary'

c. Voor één keertje mag het wel eens. Moet het.' for one time may it PART PART must it 'For one time it should be allowed. It must be the case.' 
If the main sentence is negative, as in (5b) and in (7b) and (18b) below, the negation is often repeated in the appendix (Kraak 1966; Van der Wouden 1997). Non-standard Verb-Subject word order in the main sentence is also reflected in the appendix (5c).

Sentential appendices may also take various forms: in (2b), (4a) and (4b) we already saw cases of temporal, conditional and concessive clauses, respectively. (6) shows some more of the possibilities: ${ }^{8}$

(6) a. Je moet opruimen, ook zonder dat het je gevraagd wordt. you must up-clean also without that it you asked is

'You have to clean, even without being asked'

b. Het kan erg leuk zijn, zelfs voordat je getrouwd bent. it can very nice be even before you married are 'It can be very nice, even before you are married'

c. Ze was verborgen, de wreedheid van Eenhoorn, juist omdat ze zo she washidden the cruelty of Unicorn just because she so mateloos en meedogenloos was. immoderate and merciless was 'The cruelty of Unicorn was hidden, right because of the fact that she was so immoderate and merciless ${ }^{9}$

As one can see from the examples, these sentential appendices are very often introduced or accompanied by some appropriate focus particle. ${ }^{10}$

\subsection{On the semantics of appendices}

Semantically, the appendix (be it sentential or constituent) may not only function as a clarifying addition, ${ }^{11}$ but strengthening $((2 a)$ above and $(7 a-b))$, weakening $(4 \mathrm{a}, 7 \mathrm{c})$ and even falsification $(7 \mathrm{~d})$ are possible as well:

(7) a. Ik houd van je, echt waar.

I love of you really true

'I do love you'

b. Ze heeft het niet gedaan, echt niet.

she has it not done really not

'She really didn't do it'

c. Ze is echt wel cool, soms.

she is really PART cool sometimes

'She is really cool, sometimes'

d. Je bent mijn beste vriend, maar niet heus. ${ }^{12}$

you are my best friend but not really

'You are my best friend, not'

Next to that, metalinguistic correction or comment is possible as well (cf. Horn (1989:379-382) and the references given there) ${ }^{13}$ 
(8) a. Toen gingen we iets drinken, zoals dat heet. then went we something drink as that calls 'Then we went for a drink, as it was called'

b. Jan, Riny en Henk kwamen binnen, maar niet in die volgorde. Jan Riny and Henk came in but not in that order 'Jan, Riny and Henk entered, but not in that order'

\subsection{On the pragmatics of appendices}

Pragmatically, the content of appendices is constrained in such a way that the appendix has to be more informative (in some sense) than the constituent (or whatever) in the main sentence it illucidates or modifies. In other words, the appendix must add information. In many of the examples in this paper, the appendix and the corresponding material in the main clause cannot change places, as the result violates this constraint. A few examples are given in (9): ${ }^{14}$

(9) a. ${ }^{\star}$ We gaan nog lange niet naar huis, nog niet. (cf. (2a)) we go yet long not to home yet not

b. ${ }^{\star}$ Ik kan die jongen niet uitstaan, hem $_{\mathrm{i}}$. (cf. (3a))

I can that boy not stand him

\subsection{On the phonology of appendices}

Haeseryn et al. (1997) point at yet another peculiarity of appendices: for at least some of them, there seems to be a minimum length (examples after Haeseryn et al. 1997):

(10) a. Hij keek ze één voor één aan, rustig en onverschrokken.

he looked them one for one on calm and fearless

'He looked them in the eyes one after the other, calm and fearless'

b. 'Hij greep de hendel vast, kalm.

he grabbed the handle fixed calmly

'He calmly seized hold of the handle'

One way of explaining this effect is to assume that the appendix constitutes an independent domain of intonation, an assumption that gets further support from the fact that one usually hears an independent intonational melody on the appendix. ${ }^{15}$ Especially words of one syllable often appear to be too weak to form such an independent domain of intonation, as can be seen from the contrast in (11): the imperative form $g a$ apparently needs some (phonological) support — of whatever (syntactic) type. ${ }^{16}$

$$
\begin{aligned}
& \text { a. 'Ga! } \\
& \text { go! } \\
& \text { 'Go!' }
\end{aligned}
$$


b. Ga maar/nou gauw!

go PART/PART PART

'Go!'

c. Ga weg/naar je moeder/fietsen!

go away/to your mother/bicicling!

'Go away/to your mother/away'

The same constraint may help us understand why it is impossible for single determiners and prepositions to function as appendices: ${ }^{17}$

(12) a. Ik heb een boek van Chomsky gelezen, ( ${ }^{\star}$ hét).

I have a book of Chomsky read it

'I have read a book by Chomsky'

b. Volgende week gaan we op vakantie, $\left({ }^{*}\right.$ met $) .{ }^{18}$

next week go we on holiday with

'Next week we'll go on holiday'

\subsection{Towards an analysis}

Proposals for analyses of (non-sentential) appendices are rare in the literature. In Tinbergen (1970:65), sentence (13a) is treated as a case of (asyndetic) coordination, and Sturm (1986:244) suggests that a coordinate structure underlies sentences such as $(13 b)$ :

a. Het was stil, doodstil.

it was silent dead-silent

'It was silent, very silent'

b. We hebben Pollini gezien, de beste pianist ter wereld. we have Pollini seen the best pianist in.the world

'We have seen Pollini, the best piano player in the world'

There are certain advantages in trying to analyse these constituent appendices parallel to coordination structures: coordination has been the subject of many linguistic studies and is therefore relatively well-understood; there is no shortage of proposals for mechanisms powerful enough to derive even the worst cases.

However, as Zwaan (1970) has argued for sentences such as (13a) and, independently, Van der Wouden (1994) for cases like (2a), there are strong arguments against such an analysis. One argument is syntactic in nature: if appendices are coordinate structures, then they are of a very peculiar type indeed, as they would be the only class of coordinate structures that are necessarily asyndetic: contrary to what is the case in standard asyndetic coordination (as in (14a-b)), addition of an overt coordinating element yields either a different reading or ungrammaticality (15a-b): 
(14) a. Jan, Riny en Henk kwamen binnen.

Jan Riny and Henk came in

'Jan, Riny and Henk entered'

b. Jan en Riny en Henk kwamen binnen.

Jan and Riny and Henk came in

'Jan and Riny and Henk entered'

(15) a. *We gaan nog niet naar huis en nog lange niet. (cf. (2a))

we go yet not to home and yet long not

b. ${ }^{\star}$ Het was stil en doodstil. (cf. (13a))

it was silent and dead-silent

Another argument against analysis of appendix structures as coordination is semantic: whereas standard Boolean coordination (Keenan and Faltz 1985; Zwarts 1986) deals with membership of two (or more) sets (of whatever type), appendix structures don't: appendices rather express that a certain set (the referent of the appendix) is more relevant or important or true than another one (the one referred or alluded to in the main clause).

It therefore seems preferable to follow and extend the claim of the aforementioned that we are dealing here with a construction, the first aim of which is self correction (either sincere or with rhetorical goals) rather than coordination: looking back, so to speak, the speaker retracts parts of the original utterance and replaces them by a more appropriate formulation.

If this view of appendices is correct, the appendix is essentially metalinguistic in nature: speaker (implicitly) comments on some aspect of the utterance and (explicitly) withdraws and corrects (or just adds) the relevant elements. And this means that the examples of appendices in (8), being truly, explicitly metalinguistic in nature, should not be considered peripheral or atypical at all.

If appendices are like self corrections, then there may be a close relationship with coordinate structures after all, as Levelt has shown. Concerning a sentence such as (16),

(16) Is the nurse - er - the doctor interviewing the patients?

he writes (Levelt 1989, 486)

Syntactically speaking, an utterance and its repair constitute a kind of coordination $[\ldots]$, and the syntactic rules of coordination have to be followed.

For example, sentence (16) is a well-formed coordination structure if the hesitation marker $e r$ is replaced by the coordinator or:

(17) Is the nurse or the doctor interviewing the patients?

But it remains questionable whether this approach solves all our problems concerning appendices. Firstly, most of the repairs discussed by Levelt are local in the sense 
that the error and the repair are adjacent, whereas the appendices we discuss here can be at considerable distance from the part(s) in the main sentence they are associated with. Appendix structures should in that case be more reminiscent to 'gapping' (Ross 1967). In gapping, or ellipsis in general, almost anything goes, or so it seems (Neijt 1979; Zwarts 1986; Moortgat 1988), which is a good thing, since almost anything seems possible in appendices, as we have tried to show in this paper. The fact, however, that most appendix structures do not correspond to a well-formed coordination structure makes the parallel with self repair at least questionable.

The question as to the exact structure underlying appendices is thus still unanswered and will be left for further research. However, we hope to have made it clear that whichever mechanism(s) one may choose to account for all that is possible will have to have a lot in common with the machinery necessary for coordination and ellipsis, in terms both of power and of constraints.

\section{Particles in appendices}

In the examples above, we have already seen many cases of appendices containing particles, a term which will be used loosely to refer to all kinds of adverb-like, usually small, words and word combinations (Van der Wouden 1999b). Two kinds of cases may be distinguished: either the appendix repeats a particle that is already present in the main sentence (e.g. nog in (2a)), or the appendix contains a new particle (e.g. net in (2b), vooral in (4b), etc.). As regards the first type, anything seems to go, modulo the constraints we formulated for appendices in general in Section 2 above - which explains, for instance, that many of the so-called modal particles do not occur in appendices, at least not in isolation, as they are unstressed by definition, i.e., they are incapable of carrying an intonational phrase (e.g. Vismans (1994)).

Let us now take a closer look at the second type of particles in appendices as these appear to be the more interesting ones. In our database, the top list of occurrences of particles in appendices from Dutch texts from both the Netherlands and Belgium is (in descending order) ook (as in (1b), (4b) and (6a)), wel (as in $(18 \mathrm{a})),{ }^{19}$ eens (as in (18b)), zelfs $((5 \mathrm{a}),(6 \mathrm{~b}))$, vooral (in (4a) and (5b)), alleen (as in $(\mathrm{a} 8 \mathrm{c}))$, net (as in (2b)) and zeker (18d).

(18) a. Ik ben met rytuig gekomen, en wel met een koets. I have with carriage come and PART with a coach 'I came by carriage, to wit, by coach'

b. Hij durfde haar niets te vragen, niet eens haar naam. he dared her nothing to ask not PART her name 'He dared not ask her anything, not even her name' 
c. Al mijn vrienden kunnen zwemmen, alleen ik niet. all my friend can swim PART I not 'My friends all know how to swim, but I don't'

d. Het wordt vast leuk, zeker als je van fietsen houdt. it becomes PART fun PART if you of cycling hold 'It's going to be fun, especially if you like cycling'

On the basis of this list and these examples, the appropriate generalization appears to be that most particles in appendices are of the focus type. For example: almost all cases of eens in appendices involve the fixed combination niet eens (as in (18b)) which functions as a negative focus particle (Van der Auwera 1992; Van der Wouden et al. 1998) more or less equivalent to English not even. The prime function of the equally fixed combination en wel (18a) is to introduce a further specification of what has been said, i.e., it focuses the attention on one of the possible specifications. Zeker 'certainly' has a number of usages (Dirven 1973), including one as a focus particle (Van der Wouden 1999a), like in (18d) (cf. the English translation). Further argumentation of the focus particle status seems unnecessary in the case of ook 'too', zelfs 'even', vooral 'especially', alleen 'only', etc. ${ }^{20}$

Now given the high frequency of focus particles in appendices (plus the fact that it is often possible to add a focus particle if none is present), we hypothesize that the appendix is a focus position, i.e., that appendices are in focus in the unmarked case. What does this predict for appendices? Among other things, that they will have some kind of intonational marking - which they have, as was discussed above - as all types of focused constituents are usually marked intonationally (cf. Rooth 1996).

\section{Focus and appendices}

So far, we have first sketched some general properties of appendices in Dutch. We have hypothesized that the primary function of appendices may be self correction: the speaker retracts some of the linguistic material in the main sentence and replaces it by some alternative, or adds some information.

Next, we have discussed the occurrence of particles in appendices. The fact that the majority of the particles found there is of the focus type led us to the hypothesis that appendices are in focus.

Is there a way to reconcile these two hypotheses? There probably is. According to general wisdom, the general function of focus is to evoke alternatives (e.g. Rooth (1985)). By way of illustration: the main semantic or pragmatic difference between

(19) John ate the beans.

on the one hand and 
(20) a. Only John ate the beans.

b. Even John ate the beans.

is that the latter two, but not the former, suggest that others than John might have eaten the beans; only moreover expresses that none of the alternatives is true, while by choosing even, on the other hand, the speaker conveys that all (relevant) alternatives are true, and that, of the alternatives, John was the least likely one to eat the beans.

Now in the case of self correction, we are dealing with two alternatives too, albeit at a metalinguistic level: there is one phrasing offered by the main sentence, and there is an alternative to that, evoked by the appendix. Now if the speaker puts this alternative in a focus position, e.g. in an intonationally marked appendix, the listener will infer that the alternative expressed by the appendix is the one the speaker prefers. And the focus particles found so often in appendices help to extra focus the listener's attention (or that of the reader in the case of written language) on the preferred alternative.

An additional argument in favor of our view of corrections as focus constructions can be found in the work of Van Leusen on corrections in dialogues (e.g. Van Leusen 1994). Consider the dialogue in (21):

(21) -The journalists are interviewing Arafat.

-No, they're interviewing RABIN.

According to Van Leusen, the corrected element is focused: "the focus must be contrastive with a part of the antecedent and the background must be identified in the antecedent."

\section{Concluding remarks}

In this paper, we have drawn attention to linguistic properties of appendices to Dutch sentences. On the basis of the type of particles one finds in this rightperipheral position, we hypothesized that the appendix is a focus position. We showed that appendices are often used as self-corrections, and we have given several arguments to the effect that self-corrections, and corrections in general, are very likely to be in focus, which we take as an indication that our analysis is on the right track, essentially.

\section{Notes}

* The research reported on here fits into the larger framework of the VNC-project "Partikelgebruik in Nederland en Vlaanderen", financed by NWO, the Dutch Organization for Scientific 
research, and its Belgian sister organization FWO. Thanks are due to Frans Zwarts for his help in collecting data, to the audience at the TIN-dag for discussion, and to Sjef Barbiers, Ad Foolen, Jack Hoeksema and Helen de Hoop for their comments on an earlier version. Remaining errors are mine, of course.

1. Subscripts indicate coreferentiality, as usual.

2. The traditional term in Dutch grammar is uitloop (Paardekooper [n.d.], Haeseryn et al. 1997). In real life texts, one also may find a full stop or no punctuation at all between the main sentence and the appendix. Although we do not want to claim that punctuation is uninteresting from a linguistic point of view (cf. Nunberg 1990), nothing seems to hinge on the choice in this case.

3. Particles in appendices will often be printed in bold face.

4. Traditional song.

5. In these and the following examples, untranslatable cases of particles are glossed as "PART".

6. Not everything is equal in this respect however: compare the grammatical omdat Louise de koeien heeft gemolken, met de hand 'because Louise milked the cows by hand' with the ungrammatical *omdat Louise de koeien heeft gemolken, machinaal 'because Louise milked the cows by machine' (sentences from De Haan 1976).

7. Suzanne Binnemans: Scheidslijnen: hemel en hel. Haarlem, In de Knipscheer, 1998.

8. Example (6c) shows that it is even possible for a sentence to have both a constituent appendix and a sentential one.

9. Gerard Reve: Bezorgde Ouders. Utrecht [etc.], Veen, 1988.

10. On the properties of focus particles (also known as focus adverbs) see König (1991) and Hoeksema and Zwarts (1991).

11. Verduidelijkende toevoegingen achteraf is the term used by Haeseryn et al. (1997).

12. The English equivalent of (7d) is discussed at length by Horn (1992), who dubbed it "retro-NOT".

13. In a somewhat similar construction, the grammaticalized combination sterker nog 'even stronger, or rather' introduces a (stronger) rewording of the complete main sentence: Ik houd niet van vis, sterker nog, ik haat vis/het 'I don't like fish, or rather, I hate fish/it'. The replacing element (in this case the verb form haat 'hate') is emphatically stressed.

14. Sentence (9b) improves considerably if the pronoun hem 'him' is accompanied by an appropriate gesture or something else which makes it possible to pick a particular boy from a number of candidates. But in that case, the appendix-plus-gesture again conveys additional information.

15. Another way of explaining the difference between (10a) and (10b) would be to assume that the two appendices contain adverbial material of different kinds (cf. De Haan 1976 and note 6).

16. Apparently, soms in (7c) is phonologically heavy enough to function as an appendix all by itself. Vismans (1994) has an alternative explanation (in terms of politeness) for the fact that imperatives in Dutch are often accompanied by modal particles (11b), but that explanation does not carry over to the observation that it is not just particles that improve the acceptability of bare imperatives (11c). The situation is complicated by the fact that ja 'yes', an element that is as light as $g a$, can be used as an answer all by itself, but that observation leads us far beyond the scope of this paper.

17. Syntactic, semantic and pragmatic explanations of the unacceptability of the sentences in (11)-(12) are probably possible as well.

18. Some normative grammarians prescribe the preposition met in the collocation ... vakantie gaan 'go ... holiday', so the variant with the appendix could have been informative as a self correction. 
19. When the particle wel occurs in an appendix, it most often does in the combination en wel, which looks, at first blush, like a coordination (en = 'and'). However, the combination is completely fixed and does not behave like a coordination: not only wel cannot be omitted without change of meaning (or worse), en is a necessary ingredient as well, which cannot be replaced by of 'or' or maar 'but'.

20. Some occurrences of the particle al in appendices seem to be devoid of semantic content, as in the case of hoe waaien de wimpels, al heen en al weer 'how wave the banners PART to and PART fro' and we gaan naar Zandvoort, al aan de Zee 'we go to Zandvoort, PART on the sea'. In such examples, typically coming from folk songs and second class poetry, the particle's only function seems to be prosodic: the melody to which the poem is sung dictates a pause and an extra, unstressed syllable position which is filled by al.

\section{References}

Van der Auwera, J. (1992) Dutch 'once' and related issues. In J. C. Moreno Cabrera, ed., Adverbial quantification and other adverbialia. Strasbourg: European Science Foundation (Eurotyp Working Papers 4), 49-55.

Dirven, R. (1973) 'A performative approach to German sicher and Dutch zeker'. In Abraham P. ten Cate and Peter Jordens, eds., Linguistische Perspektiven. Referate des VII. Linguistischen Kolloquiums, Nijmegen, 26-30. September 1972. Tübingen, Niemeyer, 220-229.

De Haan, G. (1976) 'Regelordening en domeinformuleringen op transformaties'. In G. Koefoed and A. Evers, eds., Lijnen van taaltheoretisch onderzoek. Een bundel oorspronkelijke stukken aangeboden aan prof. dr. Henk Schultink, Groningen, Tjeenk Willink, 279-302.

Haeseryn, W., and others (eds.) (1997) Algemene Nederlandse Spraakkunst. 2nd ed. Groningen and Deurne, Martinus Nijhoff and Wolters Plantijn.

Hoeksema, J., and F. Zwarts (1991) 'Some remarks on focus adverbs'. Journal of Semantics 8, 51-70.

Horn, L. (1989) A Natural History of Negation. Chicago, University of Chicago Press.

Horn, L. (1992) 'The Said and the Unsaid'. In C. Barker and D. Dowty, eds., Proceedings of the Second Conference on Semantics and Linguistic Theory, Ohio State Working Papers in Linguistics 40, Columbus, The Ohio State University, 163-192.

Keenan, E. and L. Faltz (1985) Boolean semantics for natural language. Dordrecht, Reidel.

König, E. (1991) The meaning of focus particles: a comparative perspective. London [etc.], Routledge.

Kraak, A. (1966) Negatieve zinnen. Een methodologische en grammatische analyse. Amsterdam dissertation. Hilversum, W. de Haan.

Van Leusen, N. (1994) 'The interpretation of corrections'. In Peter Bosch and Rob van der Sandt, eds., Focus and Natural Language Processing. Volume 3: Discourse. Heidelberg: IBM Deutschland. Working Paper 8 of the Institute for Logic and Linguistics.

Levelt, W. (1989) Speaking: from intention to articulation. Cambridge (Mass.), MIT Press.

Moortgat, M. (1988) Categorial Investigations. Logical and Linguistic Aspects of the Lambek Calculus. Amsterdam dissertation. Foris, Dordrecht.

Neijt, A. (1979) Gapping: a contribution to sentence grammar. Utrecht dissertation. Dordrecht, Foris.

Paardekooper, P. [n.d.] Beknopte ABN-syntaksis. 7th ed. Eindhoven.

Rooth, M. (1985) Association with focus. University of Massachusetts at Amherst dissertation. 
Rooth, M. (1996) 'Focus'. In Shalom Lappin, ed., Handbook of Contemporary Semantic Theory. Oxford, Blackwell, 271-297.

Ross, J. (1967) Constraints on variables in syntax. MIT dissertation.

Sturm, A. (1986) Primaire syntactische structuren in het Nederlands. Nijmegen dissertation. Martinus Nijhoff, Leiden.

Tinbergen, D. (1970) Nederlandse spraakkunst. 5th ed. by F. Lulofs and W.W.F. Voskuilen. Culemborg: Tjeenk Willink-Noorduijn.

Vismans, R. (1994) Modal particles in Dutch directives: a study in functional grammar. Vrije Universiteit Amsterdam dissertation. Dordrecht, Foris.

Van der Wouden, T. (1994) Negative Contexts. Groningen dissertation.

Van der Wouden, T. (1997) Negative Contexts. Collocation, polarity, and multiple negation. London and New York, Routledge.

Van der Wouden, T. (1999a) 'Over zeker, zeker? zeker!' Presented at the "Voorjaarstaaldag” of the BKL, Leuven, May 8, 1999, to appear in TABU, 2000 1/2.

Van der Wouden, T. (1999b) 'Smeermiddelen van de taal. Partikels in het Nederlands'. Onze Taal 68, 292-95.

Van der Wouden, T., F. Zwarts, I. Callebaut, and P. Van de Craen (1998) 'Once upon a time in Dutch'. Ms. Leiden/Groningen/Brussel, 1998, URL: http://www.let.rug.nl/ vdwouden.

Zwaan, F. 1970. 'Zelfcorrectie'. Levende Talen 264, 22-25. repr. in Zwaanzinnigh

eden, Amsterdam 1974.

Zwarts, F. (1986) Categoriale grammatica en algebraïsche semantiek. Een studie naar negatie en polariteit in het Nederlands. Groningen dissertation. 